\title{
Haruspices in het heden
}

Citation for published version (APA):

Dejong, C. H. C. (2009). Haruspices in het heden. Maastricht University. https://doi.org/10.26481/spe.20090626kd

Document status and date:

Published: 26/06/2009

DOI:

10.26481/spe.20090626kd

Document Version:

Publisher's PDF, also known as Version of record

\section{Please check the document version of this publication:}

- A submitted manuscript is the version of the article upon submission and before peer-review. There can be important differences between the submitted version and the official published version of record.

People interested in the research are advised to contact the author for the final version of the publication, or visit the DOI to the publisher's website.

- The final author version and the galley proof are versions of the publication after peer review.

- The final published version features the final layout of the paper including the volume, issue and page numbers.

Link to publication

\footnotetext{
General rights rights.

- You may freely distribute the URL identifying the publication in the public portal. please follow below link for the End User Agreement:

www.umlib.nl/taverne-license

Take down policy

If you believe that this document breaches copyright please contact us at:

repository@maastrichtuniversity.nl

providing details and we will investigate your claim.
}

Copyright and moral rights for the publications made accessible in the public portal are retained by the authors and/or other copyright owners and it is a condition of accessing publications that users recognise and abide by the legal requirements associated with these

- Users may download and print one copy of any publication from the public portal for the purpose of private study or research.

- You may not further distribute the material or use it for any profit-making activity or commercial gain

If the publication is distributed under the terms of Article $25 \mathrm{fa}$ of the Dutch Copyright Act, indicated by the "Taverne" license above, 
Haruspices in het heden

Rede

Uitgesproken bij de aanvaarding van het ambt van hoogleraar in de chirurgie, in het bijzonder de hepato-pancreato-biliaire chirurgie aan de Universiteit Maastricht

door

Dr. C.H.C. Dejong 
Mijnheer de Rector Magnificus, zeer gewaardeerde toehoorders,

'Hora septa', zei de leraar Latijn tegen de jongen. 'Hora septa, hoe laat is dat, schat je?' 'Meneer' antwoordde de jongen, 'ik ben Uw schatje helemaal niet'. De leraar werd boos en stuurde de jongen de klas uit. De ouders werden ingelicht en de jongen werd vlak voor zijn eindexamen geschorst. De jongen was hier erg door aangedaan, want hij wilde eigenlijk alleen een grapje maken. Daarnaast was hij zeer gesteld op de leraar, die altijd prachtige verhalen vertelde over de oudheid. Zijn vader hielp hem, de jongen haalde zijn eindexamen. Hij werd chirurg en met een beetje coaching om zijn scherpe kantjes bij te slijpen werd hij uiteindelijk zelfs tot hoogleraar benoemd. Peinzend over een titel voor zijn oratie gingen zijn gedachten terug naar zijn leraar. Deze vertelde ooit een intrigerend verhaal over een geheimzinnig volk, de Etrusken en hun zieners, de auguren en haruspices. Deze laatsten plachten de toekomst te voorspellen uit de ingewanden van offerdieren, waarbij vooral de schapenlever gebruikt werd. De jongen was leverchirurg geworden en keek vaak naar levers. 'Haruspices in het heden' leek hem een goede titel.

De jongen staat voor $U$. In het komende uur zal ik de titel voor $U$ begrijpelijk maken. Ik spreek - u luistert - geen weerwoord! Een droomscenario!

De Etrusken leefden in het huidige Toscane en Umbrie. Het hoogtepunt van hun macht was tussen 700 en 300 voor Christus. Daarna werden de Etrusken 'geannexeerd' en opgenomen in het Romeinse rijk. Een aantal Etruskische gebruiken werd overgenomen. Zo werden de auguren en haruspices toegevoegd aan het bestuur. Deze zieners werden steeds geraadpleegd bij belangrijke beslissingen. De 
augures, vogelwichelaars, voorspelden de toekomst uit de vlucht der vogels. Zoals gezegd voorspelden de haruspices de toekomst uit het schouwen van organen van offerdieren, waarbij met name de lever een grote rol speelde.

In een museum in Piacenza in Italië bevindt zich de bronzen lever van Piacenza. Deze werd in 1877 tijdens het ploegen van een akker gevonden. Het was waarschijnlijk een instructiemodel in de opleiding tot haruspex. Aan de mening van de haruspices werd grote waarde gehecht: zij konden dingen zien die anderen niet zagen en hun conclusies uit ogenschijnlijk onbelangrijke, onverwachte en superficiele waarnemingen waren vaak belangrijk.

Intussen is het inzicht in de anatomie van de lever sterk toegenomen door het werk van de Franse anatoom Couinaud in de vijftiger jaren van de vorige eeuw. Deze contemporaine ziener veranderde de lever van een blok vlees in een orgaan dat uit segmenten is opgebouwd en maakte zo de moderne leverchirurgie mogelijk. In het navolgende zal ik $U$ het belang duidelijk maken van de waarneming, het kijken, het zien, het beschouwen, het inzicht en de visie in de hepatopancreatobiliaire chirurgie (ofwel HPB chirurgie), de chirurgie van lever, galwegen en alvleesklier.

\section{De jonge student - het kijken en het zien}

Tijdens de studie ging de jongen niet naar college, behalve naar de lekker ouderwetse colleges chirurgie, waarbij ene professor Schmidt in witte jas voor een grote zaal stond. Deze vertelde dat de studenten het boek van Hamilton Bailey's getiteld 'Physical Signs in Clinical Surgery' moesten kopen. Als ze alleen maar naar de plaatjes keken, konden ze na een avondje stappen toch nog wat zinnigs doen. De jongen sprak met zijn vader, die huisarts was, over het boek. Deze haalde een oude versie uit de kast en gaf de jongen geld om een nieuwe te kopen. Op verloren 
momenten bekeek de jongen de plaatjes. Het prikkelde zijn belangstelling voor de chirurgie en leerde hem om ziektebeelden en symptomen sneller te herkennen. Of, om met een contemporaine voetbalwichelaar te spreken: 'Je gaat het pas zien, als je het door hebt'.

\section{Het zicht verbetert}

In de geneeskunde is de waarneming van groot belang. De grondlegger van de moderne geneeskunde, Hippocrates, vestigde reeds de aandacht op het belang van de waarneming van uiterlijke kenmerken, die wezen op inwendige aandoeningen. Zo duidt het zogenaamde facies Hippocratica op een levensbedreigende aandoening, veelal een buikvliesontsteking. Reeds in de oudheid was bekend dat deze gelaatsuitdrukking voorbode was van onheil.

Tegenwoordig is wat wij kunnen zien en waarnemen sterk verbeterd door de ontwikkeling van moderne middelen voor diagnostiek. Te denken valt hierbij aan de computer scan, de echo en de MRI. Deze ontwikkelingen hebben het zicht op de inwendige organen van de mens enorm doen toenemen en ook de therapeutische mogelijkheden sterk doen groeien. Helaas is hierdoor de kunst van de waarneming door de clinicus met het blote oog onder druk komen te staan. Te gemakkelijk wordt tegenwoordig gegrepen naar aanvullend radiologisch onderzoek.

Om $\mathrm{U}$ de kaders te schetsen waarbinnen chirurgen moesten werken in een tijd dat verfijnde aanvullende röntgen diagnostiek nog niet mogelijk was, wil ik een paar voorbeelden geven van met het blote oog waarneembare kenmerken van ziekte, die belangrijke consequenties hebben voor de behandeling van de patiënt. In deze foto ziet $\mathrm{U}$ een blauwe verkleuring van de navel. Het was Thomas Cullen die aan het begin van de twintigste eeuw er op wees dat deze blauwe verkleuring duidde op een 
bloeding in de buik bij een buitenbaarmoederlijke zwangerschap. Later bleek dit ook bij andere aandoeningen zoals een acute alvleesklierontsteking voor te komen. In dezelfde tijd vestigde de Engelse chirurg Grey-Turner de aandacht op een blauwpaarse verkleuring van de flank, eveneens bij acute ernstige alvleesklierontsteking. In deze tijd was er nog geen CT scan en kon men dus eigenlijk niet weten hoe deze tekenen ontstonden. Tegenwoordig weten we mede door de CT dat deze symptomen te verklaren zijn door lekkage van bloederig vocht langs anatomische structuren. In deze context zou je de ouderwetse chirurgen dus als een soort zieners kunnen betitelen. Andere voorbeelden van dit soort uitwendige tekenen zijn het erythema palmare, de spider naevi, uitgezette buikwand aders en het caput medusae bij verschrompeling van de lever ofwel cirrhose. De geelzucht, donkere urine en ontkleurde ontlasting passen bij verstoppingen van de galwegen. In de klassieke opleiding tot chirurg werd veel aandacht geschonken aan dit soort zaken. In een tijd dat Europese werktijdenbesluiten aan aanwezigheid van jonge dokters nog geen paal en perk stelden was het voor assistenten makkelijker om door een opleider meegetroond te worden tijdens de grote visite om dit soort bijzonderheden te aanschouwen. Ook was de beperkte toegankelijkheid van radiologische diagnostiek een dwingende reden om meer op klinische waarneming te focussen. Een van de bedreigingen van de hedendaagse gezondheidszorg is, denk ik, dat we onze jongere collega's onvoldoende kunnen opleiden in dit stuk van de geneeskunst.

\section{De jonge dokter en de meester}


De jonge dokter leerde in Schotland van zijn leermeester professor Garden het kijken naar CT-scans van de bovenbuik: "Kees, if you see the liver and the spleen, the pancreas is in between".

\section{Kliniek - van diagnostiek naar therapie}

Wat kon de chirurg in een tijd, dat aanvullende diagnostiek niet bestond? Waar begon de HPB chirurgie? In 1882 vond de eerste galblaasverwijdering plaats door Carl Langenbuch. Deze verrichtte in 1887 ook de eerste lever resectie: 'Ein Fall von Resection eines linksseitigen Schnürlappens der Leber - Heilung'. Met name dat laatste was zeer belangrijk. De patiënt overleefde de operatie en daarmee werd Carl Langenbuch's naam vereeuwigd. Zo zijn vele chirurgen beroemd en een blijvend voorbeeld voor anderen geworden. Dat Langenbuch in 1887 een leverresectie uitvoerde is des te opmerkelijker aangezien Couinaud's ontrafeling van de anatomie van de lever pas 70 jaar later gepubliceerd werd en de ether narcose pas net uitgevonden was. Hoe kon Langenbuch voorzien dat dit mogelijk zou moeten zijn? Misschien wist hij dat wel niet.

We weten tegenwoordig dat we stukken van levers kunnen verwijderen ofwel reseceren. Dit is onder andere te danken aan het feit dat de lever weer aangroeit ofwel regenereert. Dat fenomeen was op de een of andere manier al bekend in de oudheid, want het vormt het thema in de mythe waarin Prometheus door de oppergod Zeus aan de berg Kaukasus werd geketend als straf voor het stelen van het vuur bij de goden op de Olympus. Een adelaar kwam iedere dag zijn lever op eten. Heracles verloste hem uiteindelijk van deze marteling. Dit verhaal kon alleen kloppen als de lever steeds aangroeide. Door dit regenererend vermogen kunnen we dus grote delen van de lever verwijderen. 
Deze vorm van chirurgie, leverresectie genaamd, had in den beginne een hoge mortaliteit, die kon oplopen tot 30\%. Door verbeteringen in inzicht in anatomie, diagnostiek, chirurgische techniek en anesthesiologische bewaking zijn onze mogelijkheden om tumoren van de lever te reseceren de afgelopen jaren sterk toegenomen. Hieraan heeft zeker bijgedragen de CT scan vóór en de echografie tijdens leveroperaties. De moderne leverchirurg is doorgaans adequaat getraind in het zelf verrichten van leverecho's tijdens operaties. Dingen die aan het oppervlak van de lever niet waarneembaar zijn, kunnen met de echo gezien worden. De leverchirurg is op zijn manier een haruspex geworden. Mede hierdoor bedraagt de sterfte door een lever resectie nu 3-5\% in centra en is leverchirurgie hiermee veilig geworden. Om die reden zou elke patiënt met een indicatie tot lever chirurgie naar een centrum verwezen moeten worden. Dit gebeurt echter naar mijn mening niet voldoende op dit moment.

In Nederland ontstaan momenteel jaarlijks ongeveer 10000 kwaadaardige nieuwvormingen van de dikke darm, ook wel coloncarcinoom genoemd. Ongeveer $10 \%$ van deze patiënten, ofwel duizend per jaar, ontwikkelt lever uitzaaiingen met een indicatie voor resectie. Voor deze mensen is chirurgische resectie de enige kans op genezing. Helaas weten we uit onderzoek via de Nederlandse werkgroep Leverchirurgie dat in heel Nederland in 2005 slechts 540 leverresecties voor alle indicaties gedaan werden, en maar 300 à 400 voor uitzaaiingen van dikke darm kanker. Je kunt dus zeggen dat in dit millennium nog aan 600 tot 700 patiënten per jaar een behandeling voor kanker onthouden wordt met een kans op genezing van $35-40 \%$. In de afgelopen jaren zijn wel in de meeste centra in Nederland steeds meer leverresecties voor coloncarcinoom uitzaaiingen gedaan, maar nog steeds worden niet alle patiënten geopereerd bij wie dat geïndiceerd is. Hier ligt een uitdaging voor 
de Nederlandse leverchirurgen en de verwijzers: er dient een inhaalslag gemaakt te worden. Daarnaast is er aannemelijkerwijs voor de patiënt nog winst te behalen door een aantal recente ontwikkelingen, namelijk de embolisatie van de vena portae, moderne chemotherapie en de geplande leverresectie in twee stappen.

Dit alles lijkt ingewikkeld, maar ik zal trachten een en ander aan $U$ uit te leggen. Het was de Japanse chirurg Makuuchi die rond 1980 de poortaderembolisatie ofwel vena portae embolisatie bedacht. Hij nam waar dat galweg tumoren vaak de linker of rechter tak van de poortader dichtdrukken. Hij constateerde tevens dat als bijvoorbeeld de linker tak van de poortader dicht zat, de linker leverhelft schrompelde en de rechter helft een compensatoire groei vertoonde. In deze situatie, waar al een deel van de lever gekrompen was door verminderde bloedtoevoer, bleek het veiliger om een halve lever te verwijderen dan bij patiënten waar dit fenomeen niet was opgetreden. Makuuchi concludeerde dat het mogelijk was om één helft van de lever te laten groeien door de andere helft te laten krimpen. De scherpe observator, de leverschouwer, had een nieuwe behandeling uitgevonden. Ontwikkelingen in de interventie radiologie maakten het vervolgens mogelijk om de poortader door de huid aan te prikken en dan de poortadertak naar links of rechts dicht te maken met propjes, zogenaamde coils. Hierdoor krimpt één kant en de andere zijde (de toekomstige rest) wordt groter, waardoor het veiliger wordt om het aangedane deel van de lever weg te halen. Collega de Haan van de afdeling Radiologie alhier zette deze techniek met hulp van collega van Delden uit het AMC in Maastricht op.

Voor de overleving van de patiënt is belangrijk dat na operatie voldoende leverweefsel achterblijft. Uit onderzoek is bekend dat je $25-30 \%$ rest levervolume moet achter laten om de patiënt een kans op overleving na resectie te bieden. Dat 
betekent dus dat je 70 à $75 \%$ van de lever weg kan halen zonder veel consequenties. Tot voor kort was het voorspellen van het restvolume na resectie een beetje natte vinger werk. Door moderne ontwikkelingen in de radiologie is het nu mogelijk het toekomstig restvolume lever te voorspellen door metingen met de CT scan. Ook de radioloog is een haruspex geworden. Er zijn ook al programma's beschikbaar zoals ImageJ en Osirix waarmee de chirurg op een standaard PC zelf de metingen kan doen. De studenten Simon Dello en Joost van der Vorst hebben hier veel werk aan verricht.

Naast de introductie van de porta embolisatie zijn er de afgelopen 15-20 jaar belangrijke ontwikkelingen geweest op het gebied van de chemotherapie voor het uitgezaaide colon carcinoom. Eertijds gaf de oncoloog 5-fluorouracil en leucovorin volgens het zogenaamde Mayo protocol, met matig resultaat. Recent zijn daar twee krachtige middelen bijgekomen, namelijk irinotecan en oxaliplatin. Het toevoegen van deze middelen aan het Mayo schema leidde tot een aanzienlijke verbetering van de 5-jaars overleving voor de patiënt. Nog recenter zijn daar middelen aan toegevoegd die aangrijpen op de ingroei van nieuwe bloedvaatjes (bevacizumab) of de aanhechting van tumor cellen (cetuximab). Deze behandelingen zijn in combinatie succesvol en kunnen uitzaaiingen van het coloncarcinoom in de lever doen krimpen en zelfs verdwijnen. Dit heeft nieuwe perspectieven geopend.

Zo was van oudsher de situatie, waarbij zich aan beide zijden van de lever meerdere coloncarcinoom uitzaaiingen bevonden, onbehandelbaar. Tot recent werd aangenomen dat meer dan 4 lever metastasen en metastasen groter dan 5 centimeter niet chirurgisch behandelbaar waren. Door moderne chemotherapie krimpen deze gezwellen veelal, waardoor ruimte ontstaat om een leverresectie te doen. 
$\mathrm{Nu}$ is natuurlijk de vraag of resectie nog nodig is als de metastasen verdwijnen onder chemotherapie. Professor Adam en zijn Parijse groep hebben laten zien, dat 83\% van de leveruitzaaiingen terugkeert, als ze verdwijnen onder chemotherapie en je ze ongemoeid laat. Daarmee is een belangrijke vraag door onderzoek opgelost. Ook als uitzaaiingen na chemotherapie zijn verdwenen, moet een operatie plaats vinden.

Voor die situaties waarbij aan beide zijden van de lever meerdere uitzaaiingen aanwezig zijn, is ook een nieuwe oplossing verzonnen: de zogenaamde staged hepatectomy ofwel leverresectie in stappen. De chirurg besluit hier dat niet in één keer de gehele lever ontdaan kan worden van uitzaaiingen. Tijdens een $1^{\mathrm{e}}$ operatie wordt de ene zijde (bijvoorbeeld links) van de lever 'schoongemaakt'. Eventueel wordt de poortadertak naar de andere zijde (rechts) afgebonden. We maken weer gebruik van het principe dat de lever aangroeit. In een tweede operatie 6 weken later wordt dan de nog niet 'schoongemaakte' zijde van de lever gereseceerd. Ik ben collega Bemelmans erkentelijk voor de hulp bij het invoeren van dit concept in Maastricht. Soms wordt tussen de twee operaties nog chemotherapie gegeven. Recent onderzoek heeft aangetoond dat dit ertoe leidt dat met name in het centrum van de tumor versterf optreedt, terwijl in de periferie de cellen blijven leven. Men noemt dit de 'dangerous halo' om aan te geven dat hier bij de tweede operatie ruim om heen geopereerd moet worden.

Met de zojuist beschreven behandelingen kunnen we na multidisciplinair overleg vele patiënten een langere overleving bieden en in een groeiend aantal gevallen zelfs genezing.

\section{Leverchirurgie - quo vadis?}


Waar gaan we heen met de leverchirurgie? Is nog uitgebreidere chirurgie de oplossing? Waarschijnlijk slechts tot op zekere hoogte. Natuurlijk kunnen we nu beter voorspellen hoeveel lever er weggehaald kan worden. We kunnen ook door verbeterde anesthesiologische en intensive care behandeling steeds meer bij deze patiënten doen. Maar misschien moeten we ook wel slimmer naar de lever gaan kijken. We begeven ons op het gebied van het verbeteren van de weerstand van de lever tegen de effecten van de operatie. Er is nieuw inzicht ontstaan in hoe een lever aangroeit nadat een stuk is weggesneden. Waarschijnlijk spelen bloedplaatjes en het stofje serotonine een belangrijke rol in deze regeneratie.

Nog recentere ontwikkelingen zijn ontstaan door waarnemingen in herstel processen bij het zebravisje. Hier moet ik collega Olde Damink bedanken voor zijn input. Als je een stuk van de staart van het zebravisje afknipt, groeit het weer aan, net als de staart van een hagedis. Uiteraard is dit evolutionair een belangrijk fenomeen, omdat de meeste dieren met een staart deze niet voor niets hebben. De regeneratie van het staartje van de zebravis lijkt te worden gereguleerd door de zeer recent ontdekte zogenaamde microRNA's. Deze microRNA's spelen waarschijnlijk een prominente rol bij de aangroei van de lever.

Behandelingen als geïsoleerde leverperfusie en locale ablatie van tumoren zijn nooit echt doorgebroken, hetzij vanwege de aan de behandeling verbonden complicaties dan wel vanwege de hoge kans op tumor recidief. Nieuwe ontwikkelingen zijn er op het gebied van de lokale vernietiging van levertumoren door ademgestuurde bestraling en antilichaam of microsfeer gekoppelde lokale bestraling. Voor galwegkanker is er een nieuwe behandeling in de vorm van de photodynamische therapie en wellicht in de toekomst levertransplantatie. 
De uitbreiding van chirurgische behandelingsmogelijkheden zal leiden tot een toenemende behoefte aan operatiekamer capaciteit en adequaat getrainde HPB chirurgen. Naast de behandeling van coloncarcinoom uitzaaiingen zal vraag ontstaan naar behandeling van andere tumoren. Aangezien in de meeste centra de behandeling van coloncarcinoom uitzaaiingen slechts de helft van alle indicaties voor leverresecties vormt, zal snel een behoefte van 2000 lever resecties per jaar ontstaan. Zelfs met 20 levercentra zou er dan onvoldoende capaciteit zijn in Nederland.

Hoewel ik in deze oratie wil focussen op de leverchirurgie wil ik toch een paar woorden wijden aan de chirurgische behandeling van alvleesklierkanker, met name van de kop van de alvleesklier. Hoewel de diagnostiek van deze aandoening sterk verbeterd is, wordt de aandoening veelal laat ontdekt en heeft een slechte prognose. De tumor groeit snel in belangrijke bloedvaten in, wat chirurgie moeilijker, zo niet onmogelijk maakt. Bestraling draagt niet bij, geeft meer complicaties en is belastend voor de patiënt. Chemotherapie heeft beperkt effect en geneest niet. Uitgebreide operaties met vervanging van bloedvaten en verwijdering van lymfeklieren hebben geen verbetering van overleving gebracht, maar wel het operatierisico voor de patiënt vergroot. De klassieke Whipple operatie is veilig geworden in grote centra en geeft een goede kwaliteit van leven. Als deze operatie niet mogelijk is, is een zogenaamde palliatieve dubbele bypass operatie een goede optie.

\section{De jonge dokter en de Dood}


De jongen dacht aan de dodensteden van de Etrusken. Rond 600 voor Christus vond bij de Etrusken de overgang van crematie naar inhumatie plaats. Zij begroeven voort hun doden in een dodenstad, een necropolis.

Welke prijs betalen wij, dokter en patiënt, voor de steeds agressievere medische behandelingen. Iedere behandelingsmethode heeft zijn inherente complicaties. De meest ernstige daarvan is de dood. Wat betekent de dood in de chirurgie? Ik heb het altijd moeilijk gevonden aan anderen duidelijk te maken wat het betekent als een patiënt ten gevolge van complicaties van een operatie overlijdt. Je gaat een professionele verbintenis aan met een patiënt, maar boven alles, een band met een ander mens. Daarin is het ultieme vertrouwen dat een ander zijn leven in jouw handen legt. Dat is een eer, maar ook een last. Dokters, en zeker chirurgen, praten daar niet vaak, en misschien ook wel niet graag over. Zij worden beschermd door een kort geheugen, maar in het hoofd van elke chirurg waren geesten.

Ik wil een paar woorden wijden aan de levertransplantaties. Wij hebben in 2002 een Maastrichts orgaan uitname team geformeerd. We zouden ook wel ooit zelf willen gaan transplanteren, wellicht in samenwerking met Aken of Leuven, maar overheidsbeslissingen maken dat op dit moment onmogelijk.

Het op technisch correcte wijze uitnemen van organen is cruciaal, om voor de ontvanger een veilige transplantatie garanderen. Een belangrijk aspect is het beoordelen van de kwaliteit van de organen tijdens de uitname. Hierbij weten we dat de lever, en met name de vervette lever, zeer kwetsbaar is voor gebrek aan doorbloeding en zuurstof. Dit is toenemend een probleem aangezien de mens wereldwijd dikker wordt. We nemen aan dat $30 \%$ leververvetting de bovengrens is bij meer dan 30\% wordt de lever ongeschikt verklaard. Het beoordelen van de mate 
van leververvetting geschiedt nog steeds met het blote oog tijdens de donor operatie. De chirurg voorspelt de toekomst van het orgaan uit de waarneming van de lever.

Het orgaanuitname team gaat meestal buiten kantooruren naar andere ziekenhuizen om daar bij hersendode patiënten organen uit te nemen. Dit is voor een arts eigenlijk een bizarre taak, aangezien er geen band is met patiënt of familie. Als het om een uitname procedure bij een kind gaat, is dat emotioneel belastend. Toch moet dit gebeuren, omdat anderen hierdoor weer verder leven. Mijn kinderen begrepen aanvankelijk niet waarom ik bij nacht en ontij op pad ging om dit te doen het scheen hen een beetje luguber toe. Van elke procedure krijg je echter later een verslag met de terugkoppeling welk orgaan bij wie geïmplanteerd is. Ooit gaf ik mijn kinderen zo'n brief, met de vermelding dat een volwassene en een kindje ieder een nieuw leven kregen door een procedure waarbij een deel van de donorlever aan het kind wordt gegeven en de andere, grotere helft aan een volwassene, en dat daarnaast nog twee nieren, een hart en de longen, en ook een alvleesklier getransplanteerd waren. Daarna vonden ze het begrijpelijk dat chirurgen zich hiervoor inspannen. Een nacht doorwerken is voor een mens verwaarloosbaar tegen de achtergrond van de verlichting van andermans lijden. Ik pleit er daarom voor dat iedereen orgaandonor is tenzij hij uitdrukkelijk aangegeven heeft dat niet te willen zijn.

\section{De jonge onderzoeker}

De jonge dokter ontmoette professor Soeters en werd overtuigd van het belang onderzoek te gaan doen. 
Het is niet voldoende om in de chirurgie alleen aandacht te besteden aan patiëntenzorg. Om grenzen te verleggen, is het belangrijk onderzoek te doen. Klassiek wordt hier onderscheid gemaakt tussen basaal wetenschappelijk onderzoek en klinisch toegepast onderzoek. Het basaal onderzoek dient idealiter te leiden tot bevindingen, die vertaald worden naar de praktijk. Het is belangrijk dat chirurgen zich blijven verwonderen over klinische waarnemingen, dat zij daar vragen uit destilleren en deze meenemen naar de prekliniek, om met basaal onderzoek deze vragen op te lossen.

Wij verkeren in Maastricht door de visie van mensen als Greep en Soeters in de gelukkige omstandigheid dat we een uitstekend onderzoekslaboratorium hebben. Daar wordt onderzoek verricht op het gebied van de stofwisseling en de immunologie, aansluitend bij de klinische speerpunten. Dit onderzoek is ingebed in de onderzoeksschool NUTRIM. Recent hebben collega Poeze en Olde Damink beide een persoonsgebonden ZonMW subsidie verworven voor research op het gebied van sepsis en leverfalen, respectievelijk, hetgeen een krachtige stimulans is voor het heelkundig onderzoek in Maastricht.

Een speerpunt in het onderzoek is de zoektocht naar de achtergrond van leverfalen na resectie. Zoals eerder aangegeven kan ongeveer $70 \%$ van de lever bij de meeste patiënten verwijderd worden, maar niet bij iedereen. Soms is het geen probleem $75 \%$ van de lever te verwijderen, soms gaat het bij $60 \%$ al mis. Klaarblijkelijk is de ene lever gevoeliger dan de andere. Onbekend is wat de meest belangrijke functie is, die tekort schiet bij leverfalen na resectie. Hoewel mensen meestal onder het beeld van een ammoniak vergiftiging overlijden, heeft eigen onderzoek aangetoond, dat dat niet de cruciale functie is die faalt. Wel weten we uit onderzoek met de vakgroep chirurgie in Edinburgh dat het immuunsysteem van de 
lever tekort schiet. De lever kan in deze situatie niet meer alle bacteriën die uit de darm ontsnappen wegvangen. In het kader van deze darm-lever interactie hebben we de afgelopen jaren onderzoek gedaan naar effecten van vetrijke voeding op darmbarrière en bescherming tegen de postoperatieve ontstekingsreactie.

We weten daarnaast dat de lever kwetsbaar is voor tijdelijke onderbreking van de doorbloeding. Tijdens leverchirurgie wordt vaak de zogenaamde Pringle manoeuvre toegepast, waarbij de bloedtoevoer van de lever tijdelijk afgeklemd wordt om tijdens het doorsnijden van de lever minder bloed te verliezen. Een van de onderzoekslijnen focust op leverschade door de Pringle manoeuvre.

Tenslotte doen we onderzoek naar leverschade door oxaliplatin voorafgaand aan de leveroperatie. Leverchirurgen hadden al snel in de gaten dat, als een patiënt langdurig preoperatief oxaliplatin had gekregen, de lever een merkwaardig blauw aspect had: de 'blue liver'. Bij patiënten die zo'n blue liver hadden ontstonden na de operatie vaker problemen. De haruspex-leverchirurg kon de toekomst voorspellen, maar wist de oorzaak niet. Inmiddels hebben we met professor Wisse een fixatietechniek ontwikkeld om lever voor elektronen microscopie geschikt te maken. Daardoor kunnen we veel gedetailleerder zien dan het simpele 'leverschouwen'.

\section{De jongen droomt}

De Etrusken leefden in een dodecapolis, een stadstaat bestaande uit twaalf steden, die ieder een rol hadden in het staatsbestel. Er was geen epicentrum van macht.

Voor vele aandoeningen op HPB gebied geldt dat per centrum te weinig patiënten gezien worden. Het is mijn droom dat we komen tot een 'Nederland is Etrurie' idee. Alle centra werken eendrachtig samen aan een betere gezondheidszorg in een 
stadsstaat zonder epicentrum van macht. Voor zeldzame aandoeningen wordt gestreefd naar centralisatie. Voor ontstekingen van de alvleesklier hebben we hiertoe sinds 2001 een fantastische werkgroep onder leiding van professor Gooszen uit Utrecht. Dit heeft geleid tot twee trials met belangrijke conclusies ten aanzien van de behandeling van deze gevreesde ziekte, waaraan in 2000 nog 1 op 3 patiënten overleed indien chirurgische behandeling noodzakelijk was. Inmiddels is de sterfte door dit initiatief gedaald tot 15\%. Dit samenwerkingsinitiatief wordt wereldwijd met grote belangstelling bekeken. Misschien mag ik hier collega Gooszen de Haruspex van de pancreatitis noemen. Binnen de leverchirurgie zijn vergelijkbare initiatieven ontplooid en lopen nu ook drie trials.

\section{De jonge opleider}

De jonge opleider herinnerde zich dat in de cultuur van de Etrusken vrouwen in het sociale leven gelijk waren aan mannen. Dit was zeer wezenlijk anders dan bij de Romeinen en de Grieken.

Opleiden en kennisoverdracht zijn in mijn visie zeer belangrijk. Het was dan ook een eer voor me toen ik een aantal jaren geleden de kans kreeg met collega Greve de opleiding Chirurgie te trekken. Greve werd opleider en ik plaatsvervangend opleider. Het is belangrijk om collega's op te leiden, om in de toekomst onze taak over te nemen. De opleiding is de afgelopen jaren gemoderniseerd en daar zitten goede dingen in. Het Nederlandse opleidingsplan is een voorbeeld voor ons omringende specialismen en landen. Controle op kwaliteit en transparantie van competenties zijn nuttige vernieuwingen in de opleiding tot medisch specialist. Daar staat tegenover dat dit tot een enorme toename aan administratieve taken voor opleiders en 
opgeleiden heeft geleid. Objectieve beoordelingen van technische vaardigheden en korte klinische beoordelingen hebben er toe geleid dat we over zaken opener praten en dat is een groot goed. Zolang echter deze instrumenten niet meten wat wij willen, is er nog veel werk te verrichten. Een elektronisch portfolio is dringend gewenst, mede om de stapels papier die onnodig geproduceerd worden, te reduceren. Arbeidstijdenbesluiten en parttime werken hebben flexibiliteit geëist van de zittende orde. Ook de intrede van vrouwen in 'het vak' heeft menig chirurg en opleider voor een opgaaf gesteld. Hier kunnen we wellicht van de Etrusken leren.

Er dreigt een wildgroei aan vergaderingen en visitaties te ontstaan om de kwaliteit van de opleiding te borgen. Hierdoor lopen we het risico dat een opleider meer en meer een papiertijger wordt. Dat staat haaks op hoe bepalend de rol van individuen in de loopbaan van veel chirurgen is geweest. Goed voorbeeld doet volgen en in dat licht ben ik een groot voorstander van het behoud van het meestergezel systeem. Het is een misvatting, dat dit aan het verdwijnen is. Mensen herinneren zich een persoon, niet een systeem.

Door het vertrek van collega Greve promoveerde ik recent ongewild tot opleider. Naar mijn mening had en heb ik onvoldoende tijd om, naast mijn voortrekkersrol in de HPB chirurgie, deze taak naar behoren uit te voeren. Een ander team moet dit beter kunnen. Ik dank dan ook de staf en professor Jacobs voor hulp bij het uitwerken van een scenario waarbij de opleiding binnenkort door collega Stassen wordt voortgezet, met collega van Helden als waarnemend opleider. Dit duo zal de opleiding verder verbeteren en daarmee treed ik met een gerust hart terug.

In een steeds vroeger stadium van de studie Geneeskunde komen studenten tegenwoordig in de kliniek terecht. Het onderwijs is praktischer en jonge dokters in spe krijgen vroeg verantwoordelijkheid voor patiënten. Met het helaas teruglopend 
aantal assistenten en het groeiend aantal nurse practitioners ontstaat een gezondheidszorg systeem dat in toenemende mate leunt op steeds jongere mensen. Dat is goed gezien het vroege contact dat jonge dokters met patiënten krijgen, maar aan de andere kant moeten we er ons van bewust zijn dat met name in grote ziekenhuizen er patiënten met steeds complexere pathologie liggen.

Kwaliteitscontrole en regievoering op het niveau van de staf chirurgie is hier cruciaal.

\section{Kliniek, onderzoek en opleiding hand in hand}

In het afgelopen decennium heeft onze afdeling in Nederland en Noord Europa een belangrijke rol gespeeld in de modernisering van de zorg rondom grote operaties. Door toepassen van op wetenschap gebaseerde interventies is het mogelijk een patiënt na een dikke darm operatie eerder te laten eten, drinken en mobiliseren. Mensen herstellen zo sneller en zijn eerder in staat om naar huis te gaan. Maastricht heeft hierbij als referentie centrum gediend in 3 CBO projecten, waarbij ons zorgprotocol ingevoerd werd in meer dan een derde van het totale aantal ziekenhuizen in Nederland met als resultaat een versneld herstel en daardoor een afname van opnameduur van 3 dagen. Inmiddels is dit concept door collega van Dam ook bij de leverchirurgie toegepast. De ondersteuning van de verpleging, met name Kim en zuster Marjo, van Jose Maessen van de afdeling Diëtetiek en collega von Meyenfeldt, en het CBO is hierbij onmisbaar geweest.

We proberen de zorg voor patiënten steeds verder vast te leggen in zorgpaden, waarbij de bedoeling is dat de tijdsspanne tussen eerste poliklinische bezoek en ontslag na operatie korter wordt. De diagnostiek vindt in een 'one stop shop' plaats, waarna de patiënt multidisciplinair besproken wordt. Na een poliklinisch vervolgconsult kan de operatie gepland en uitgevoerd worden. Uitvoerige voorlichting 
van de patiënt speelt hierin een steeds belangrijkere rol, waarbij een terechte taakverschuiving plaats vindt van arts naar gespecialiseerd verpleegkundige. Voorlichting door deze professionals is bewezen effectiever dan door een dokter.

Door bestuurlijke druk en reductie van het aantal bedden is een capaciteitsprobleem ontstaan in ziekenhuizen. Dit heeft geleid tot afname van de gemiddelde opnameduur en tot het toenemend uitvoeren van operaties in dagbehandeling of via een kort verblijf afdeling. Niet iedere patiënt is hier blij mee. Deze ontwikkelingen vragen om verandermanagement, hetgeen vraagt om inzet van personeel. Dit dient mijns inziens niet aan de management-laag van de organisatie te worden toegevoegd, maar gepositioneerd aan de rand van het bed, samen met de chirurg. Directe interactie met de patiënt is effectiever dan protocollen die worden opgelegd.

\section{Algemene chirurgie en leiderschap}

Binnen de algemene chirurgie is er toenemend sprake van differentiatie in deelspecialismen. Waar een chirurg eertijds de gehele breedte van het vak afdekte, hebben we tegenwoordig vaatchirurgen, ongevalschirurgen, kinderchirurgen, transplantatie chirurgen, en de gastrointestinaal chirurgen en oncologisch chirurgen, samen zeg maar de buikchirurgen. Patiënten worden ook steeds vaker alleen nog door super-specialisten gezien. Daarmee valt een stuk binding tussen de subdisciplines weg. Het toenemend multidisciplinair behandelen van patiënten maakt dat een buikchirurg vaak meer contact heeft met een maag-darm leverarts dan met zijn collega traumatoloog. Multidisciplinaire besprekingen, poli's en behandelingen maken dat de zorg steeds meer thematisch rond de patiënt georganiseerd wordt. Dat geldt ook voor de HPB chirurgie. 
Tegen die achtergrond wordt de discussie belangrijk wie wat doet. Moeten chirurgen nog endoscopieën doen, of is dat iets wat we aan onze collega's van de MDL ziekten moeten toevertrouwen. Mijn mening is dat iedereen vooral moet doen waar hij of zij goed in is. Een chirurg moet goed zijn in opereren, en een MDL arts in endoscopieën. Het zou mijn visie zijn, dat MDL artsen en chirurgen een afdeling met een aantal bedden gemeenschappelijk bestieren. Dat is in het belang van de patiënt en zal de efficiëntie in het ziekenhuis doen toenemen.

Binnen de buikchirurgie is intussen al weer verdere specialisatie te zien. Chirurgen specialiseren zich in aandoeningen van het bovenste of onderste deel van het maagdarm kanaal, of in de HPB chirurgie. De overheid oefent druk in deze richting uit door aandringen op certificering en dat heeft tot de formalisering in de vaatchirurgie en traumatologie geleid. Een vergelijkbare ontwikkeling is in gang gezet in de gastrointestinale en oncologische chirurgie. Het is opvallend dat chirurgisch Nederland het hier eens lijkt dat we orgaangericht moeten werken. Dit wordt ingegeven door het feit dat een chirurg die een bepaalde operatie vaker doet, betere uitkomsten heeft in termen van complicaties inclusief sterfte rondom een operatie. Dit geldt ook voor de HPB chirurgie. In Limburg heeft dat geleid tot concentratie van slokdarm chirurgie in Heerlen, en de HPB chirurgie in Maastricht.

Het is een kwestie van tijd en dan opereert een buikchirurg geen bloedvat meer en een traumatoog geen darm. Gespecialiseerde HPB chirurgen zullen alle galblaasoperaties gaan doen en zo voorts. De opleiding is hier al op gericht en zonder twijfel ziet chirurgisch Nederland er over 10 jaar anders uit. Ik denk dat dit ook een goede ontwikkeling is, maar alles heeft een prijs. Zo zal dit leiden tot verbetering van de kwaliteit van zorg overdag, maar de vraag is of dit ook geldt voor nacht- en weekenddiensten. Toenemende differentiatie leidt er immers toe dat er straks te veel 
chirurgen dienst moeten doen voor ieder een klein gebiedje. Dit zal in kleinere maatschappen chirurgie logistieke problemen opleveren.

Ook voor onze eigen vakgroep ligt deze uitdaging er. Discussies over differentiatie op het niveau van ziekenhuizen alsook binnen de vakgroepen lopen parallel en door elkaar. Waar ooit het ziekenhuis in Maastricht op Calvariënberg startte als stadsziekenhuis, groeide dit later naar een stads- en streekfunctie. Het academisch ziekenhuis in Maastricht heeft een bijzondere positie. In andere steden, die een universitair ziekenhuis hebben, is namelijk een zogenaamd perifeer of stadsziekenhuis aanwezig. Alleen in Maastricht is dat niet zo en moet het academisch ziekenhuis ook de zeg maar 'gewone zorg' leveren. Daardoor moeten de chirurgen in Maastricht in de dagdagelijkse praktijk rekening houden in de planning met een groot aantal operaties dat in andere academische ziekenhuizen niet gedaan hoeft te worden. Dit nadeel in academische zin heeft natuurlijk het voordeel dat er veel operatieve ingrepen beschikbaar zijn voor opleiding.

Avantis, de samenwerking met Aken en de alliantie met het Maxima Medisch Centrum zorgen in dit licht voor uitdagingen, maar ook voor potentiële bedreigingen op vakgroep niveau en in de opleiding. Goed leiderschap is hier belangrijk. Een leider wordt gedragen door diegenen die hem tot leider hebben gekozen. Van de andere kant hebben de 'onderdanen' alleen een leider als ze hem als leider dragen.

\section{De jonge professor en de verwondering}

In Amsterdam ontwaarde de jonge professor deze frase op de tympaan van een gebouw. 'Homo sapiens non urinat in ventum' - 'Een wijs mens pist niet tegen de wind in'. 
Hoe komt deze tekst daar? De architect had dit voor de grap op de tekening gezet en een commissie van wijzen heeft hier over heen gekeken. De burgemeester keek bij de opening wel raar op en heeft nog geprobeerd de tekst te laten verwijderen, maar hier heeft de architect succesvol protest tegen aangetekend.

De academie is geen gemakkelijke plek om de chirurgie te bedrijven. Vele zaken leiden af van datgene waar het uiteindelijk om gaat: de patiënt. Het is zo ongeveer een vereiste om een dubbele agenda te hebben, en dan bedoel ik niet een PDA en zo'n klein boekje, nee, veeleer bedoel ik de verborgen agenda's. Dat heeft me wel wat moeite gekost in het begin van mijn loopbaan. Integriteit en eerlijkheid hebben in mijn opvoeding en leven steeds een belangrijke rol gespeeld. Op den duur moet je echter geen Don Quichotte worden.

\section{Levertraan}

Deze woorden zijn voor diegenen die hier zijn. Ik wil jullie graag bedanken voor de aanwezigheid en steun in de afgelopen jaren. Ik heb ook vast in mijn betoog mensen vergeten. Ik hoop dat diegenen bij dezen mijn woord van dank aanvaarden. Daarnaast zijn er ook een paar woorden voor diegenen die hier niet meer zijn. Mijn vader. Mijn moeder Anne, die ooit voorspelde dat ik professor zou worden. Ik weet niet of de Etrusken ook vrouwelijke Haruspices hadden.

Ik ga $U$ als afsluiting het verhaal van Sainte Odile vertellen: la patronne des aveugles - de patronesse van de blinden. Degenen die niet kunnen zien. Kunnen die Haruspices zijn? Sainte Odile werd geboren als dochter van een graaf in een tijd dat het krijgen van een dochter als eerstgeborene geen goede zaak was. Het meisje was bovendien blind en werd te vondeling gelegd. Een aantal religieuzen ontfermde zich 
over het kindje en zo groeide Odile op. Zij stichtte een orde nabij Obernai in de Elzas boven op een berg. Met haar staf sloeg zij op de grond en een bron ontstond. Degene die zijn ogen depte met het water zou naar verluid het zicht herwinnen. Ik ben ooit hier met een zwangere vrouw de berg afgedaald door het schemerige bos om mijn en haar ogen te deppen met het water van de bron van Saint Odile, in de hoop dat zij en ik en de eerstgeborene daar voordeel bij zouden hebben. Wel, van ons gezin zijn wij de enige drie met een bril. Of ik daardoor ook visie heb gekregen zal de toekomst leren. Ik kan die niet voorspellen.

Ik heb gezegd 